Utah State University

DigitalCommons@USU

All U.S. Government Documents (Utah Regional U.S. Government Documents (Utah Regional Depository)

1981

\title{
Geologic Map of the Steamboat Mountain and Bible Spring Quadrangles, Western Iron County, Utah
}

Myron G. Best

Robert L. Davis

U.S. Geological Survey

Follow this and additional works at: https://digitalcommons.usu.edu/govdocs

Part of the Geology Commons

\section{Recommended Citation}

Best, Myron G.; Davis, Robert L.; and U.S. Geological Survey, "Geologic Map of the Steamboat Mountain and Bible Spring Quadrangles, Western Iron County, Utah" (1981). All U.S. Government Documents (Utah Regional Depository). Paper 561.

https://digitalcommons.usu.edu/govdocs/561

This Report is brought to you for free and open access by the U.S. Government Documents (Utah Regional Depository) at DigitalCommons@USU. It has been accepted for inclusion in All U.S. Government Documents (Utah Regional Depository) by an authorized administrator of DigitalCommons@USU. For more information, please contact digitalcommons@usu.edu.

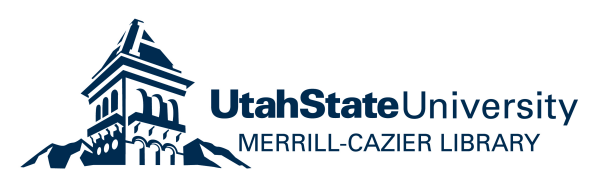


DEPARTKEMT OP THE IHTBRIOR

W"YITED STATES GEOLOGICAL SURVET

GEOLOGIC MAP OP THE STEAMBOAT MOUTTAIM AMD BIBLE SPRTIG QDADRAMGLES,

EESTERI IRON COOMTY, UTAB

Myron G. Beat and kobert L. Davis

Geology aapped in 1980 with the assistance of Leh1 p. Hintze and etudents in the Brighan Young University sumar geology fleld course

OPEM-YILE REPORT 81-1213

1981

Th1s report 1s preliainary and has not been adited or revlewed for conforalty
with U.S. Geological Survey standards.

\section{DESCRIPTION OF MAP UNTTS}

NLLUVIOM AND COLLUVIOM (QUATERRARY)-Onconsolidated, poorly sorted atream-, fan-, and slope-sash deposits of eand and gravel.

Includes colluvial debris and talus from units Tf, Trs, and Tba. Northvesz and west of Meadow Spring, in the east-central part of the map area, the unit consists in part of a high-level erosional rearnt of older fan or pediment deposits consisting chlefly of debris from unit Trs with sparse boulders frow unit Tf. Th1ckness ranges froa 0 to more then $40=$ BASALT LAVA FLOWS (MIOCERE)-Dark-gray, locally vesicular and anygdaloldal lava flows with sparse phenocryets of ollvine. Boulders in unit Qac northwest of Meadow Spring, possibly derived froa flows that once capped Steamboat Mounta1n, also have phenocrysts of augite and plagioclase and closely resemble flow rocks of potassic basalt in the southvest corner of the Frisco quadrangle to the northeast which have gielded wholerock R-Ar ages of about $13 \mathrm{~m} . \mathrm{y}$. (Abbott and others, 1981). Th1ckness west of North Trovg:. Spring along the south margin of the map area is 10 a

Td brown, gray to purple, atrongly porphyritic dacite with proalnent phenocryats of sanidine and plagioclase ranging up to 3 ca across and anor smaller pheaocrysts of quartz, blotite, horablende, and augite in a alcrocrystalline felsic antrix. Probably a lava flow-voleanic dome couplex that is more than 250 a th1ck 

hydrotheraally altered areas, as at Bob Leroy Peaks and south of Typhold Spring, near the center of the map area. The rhyolite body on the west side of uilson Canyon 1n secs. 6 and 31 is interpreted to be a shallow 1ntrusion emplaced along a anjor fault zone, although the alternative view that it is an extrusion predating deposition of the tuff of Ryan Spring ( $T r$ ) cannot be ruled out. Several R-Ar deterainations on san1dines (R. B. Mehnert, vritten comun., 1981) 1ndicate an age of about $12 \mathrm{~m} . \mathrm{y}$. Maximum thickness of 1ndividual flows is locally as 11ttle as $30 \mathrm{~m}$, whereas the1r aggregate thickness at Steamboat Mounta1n 1s about 500 a

heterogeneous sequence of generally poorly exposed

volcaniclastic and minor epiclastic deposits associated with exuption of the rhyolite of Steamboat Mountaln $(12 \mathrm{m.y}$.) and rhyolite units 10 the foration of Blawn wesh $(22-20 \mathrm{~m} . y$.$) . Is$ widespread in the southern Wah Wah Kountains northeast of anp area (see Abbott and others, 1981). Tan to pale-green-brown or p1nk, weakly welded ash-flow and minor alr-fall tuff is wost comon and occurs as layers a fev contimeters to a fev meters th1ck containing as wuch as 30 percent puaice lap1111; sparse phenocrysts less than 3 = across of quartz, feldspar, blotite; and var1able quantities of dark-colored 11thic fragments froe units Irs, Tcb, T1, and Tnl. Locally, as at thite Cliff, angular 11thic fragments as large as 1 w across and composing as wuch as half of the rock were derived entirely from unit Trs, probably 1ndicating disinzegration of a nearby voleanic dose. These tuffs represent explosively erupted anterisl frou any local vents that later vere sources of viscous lava flows. Dait includes sparse crudely stratified bede of tan, coarse sandstone, locally with cobbles of unit Tnl, snd beds of red, poorly sorted angular olcanic debris of sand to cobble size. Locally sillelfied io form resistant anses of white to tan Jasperoid. Comanly 100-200 = thick, but locally any be more 
Phenocryats of sanidine and plagioclase ranging up to $2 \mathrm{ca}$ acroes conatitute almost half of the rock; some feldopar cryatals have rias of chalky plagloclase surrounding glassy sanidine cores. Sparse emall phenocrysts of hornbleade and biotite are as wuch as a alliseter in diaseter. The unit is aletlar to the rhyolite of P1nk Rnolls exposed in the Tetons and observation Knoll quadrangles to the northeast of the anp area (Best and Keith, 1979)

sonolithologic and heterolithologic brecciss and megabrecclas that apparently foraed by slumping and fluvial transport of debris froa older rock units into fault-controlled basins at the south end of the Bible Spring fault zone. In the anin area of exposure in sec. 13 the unit forms a hillslope rubble ierived froe units $T 1, T c b$, Tha, and $T t$; clasts range froe sand size to shattered and pervasively ollckenslided slabs tens of meters 1ong. B1sewhere, th1s unit consists mostly of monollthologic brecc1sa derived froa un1t Tcb; clasts range up to several meters in diameter. Local sandstones and conglomeratic mudflows contain clasts derived malnly froe unit Tha. The rocks were coemonly affected by weak heastitic alteration and sillcification. Thickness any be as wuch as eeveral hundred meters

HORNBLENDE ANDESITE (MIOCENE AND OLIGOCENE)--Locally ves1Cular 1nteraediate-couposition lava flows that are gray to black where freah and red brown where altered. Proalnent1y porphyritic with 25 percent phenocryots consisting aninly of actcular hornblende and zoned plagloclase, and lesser mall augite and hypersthene grains. Matrix 1s a felty aggregate of feldspar and glass. Un1t ranges up to $250 \mathrm{~m}$ in thickness

MAPIC FLOW MERBER OP THE PORMATION OF BLAWN WASH (MIOCENE)-Massive to slightly vesicular porphyritic lava flows that weather red brown with 11esegang bends; phenocrysts of amber to white plagioclase as much as $1 \mathrm{~cm}$ long and saniler augite and hypersthene compose 10 percent or less of the rock and $11 \mathrm{e}$ in a black alcrocrystalline to glassy aatrix. Locally, consists of weakly porphyritic lava flows with alcrophenocrysts of ollvine, plagloclase, and sparse san11 plates of phlogopite in an aphanitic matrix. Similar lava flows of trachyandesite occur In about the ame stratigraphic position in the Wah Wah Mountalns east and north of map area, where a vhole-rock $\mathrm{R}$-Ar age of 23.2 \pm 1.0 a.y. (Abbott and others, 1981) has been deterained. A local lava flow contalning phenocrysts of blotite and hornblende in addition to plagloclase and pyroxene, exposed about 1.5 alles $(2 \mathrm{~km})$ wortheast of Span1sh George Spring in southrest part of ap area 1s 1ncluded in the unit, as 1s a vell-sorted green sandstone near Bob LeRoy Peaks. Thickness 1s at least $100 \mathrm{~m}$ in Trall Draw in south-central part of map area 
set in a red matrix of velded ash. Thickness ranges from 0 to about 120 a

ISOM FORuTION (OLICOCENE)--Red-brovn to purple, crystal-poor ashflow tuffs and lava flows that weather to small plates and popcorn-11ke grus. Phenocrysts generall1y const1tute less than 15 percent of the rock and 1nclude plagioclase with ainor, wuch gasller pyroxenes and $\mathrm{Fe}-\mathrm{TI}$ oxides. Tuffs are vuggy and densely welded with intensely compacted and locally elongated pumice fragments. Age 1s about $25 \mathrm{a} . y$. (Fleck and others, 1975). Thickness ranges froa as 11tele as $10 \mathrm{a}$ in the northeast corner of the anp area to possibly more than 800 a fust north of Negro L1za Wash where a variety of lava flows and ash-flow tuff units with 11thologies siallar to the Isou are exposed

LUND TUFP MERBER OF THE MEEDLSS RANGE PORATTION (OIIGOCENE)--Redbrown moderately to Intensely velded ash-flow tuff with about 10 percent quartz, 25 percent plagioclase, and 10 percent blotite and lesser hornblende. Flattened, 11ght-colored puarice lap1111 are proalnent in most outcrops but sall 11th1c fragments are present only locally. Blotite from this unit ylelds a R-Ar age of about $28 \mathrm{m.y}$. (B. H. Mehnert, vritten commun., 1981). Thickness 1s uncertain because of extensive and probably undeteteted faulting but may be as great as 750 m; th1s thickness is belleved to reflect accumulation in a deep moat between the now-bur1ed southeast topograhic vall of the Indian Peak caldera (Best and others, 1979), and theresurgent dome of the caldera that now exposes units Tab and Tnw1 in the northvest part of the anp area

TUPF OR RYAN SPRING (OLIGOCENE)--Var1egated 11ght-gray to lavender crystal-poor ash-flow tuffs. Phenocrysts of plagioclase and whor blotite less than 2 across constitute 20 percent or less of the rock. Dark-colored flattened punice lapill1 are locally conspicuous. Astr-flow tuffo may be as thick as 500 m along the north margin of the map area but probably thin southward 
(OLICOCENE)--Poorly exposed heterogeneous brecclas formed by caving of the unatable valls of the Indian Peak caldera dvcing 1to eploodic collapse. Clasts as wuch as 0.5 m 1 in diameter are froe units Thul and Te as well as from stratigraphically undivided volcanic unite of intermedite composition. In the northeast corner of sec. 36, T. 31 T., R. 18 w., gnelsses and other deep crustal rock types are 1ncluded in the breccia

ESCALANTE DESERT FORMATION (OLIGOCERE)--Sandstone, welded ash-flow tuff, and porphyritic andesitic lava. Where undivided in the southeastern part of the map area the unit 1ncludes: (1) a well-sorted but poorly bedded green-brown sandstone; (2) pink to lavender, firaly welded ash-flow tuff with about 20 percent plagloclase and blotite phenocrysts, conspleuous 11thic

fragaents, and flattened punice lapil11; and (3) a red, gray to green-black plagloclase-phyric lava flow

Tea Andesite meaber-Gray, red-brown weathering, generally nonvesicular lava flows with phenocrysts of pyroxene and plagioclase in a finely granular aatrix. Thickness about $100 \mathrm{~m}$ Tera Tuff member of Marsden Spring--Light-gray to tan, firaly velded, ash-flow tuff with only a trace of feldapar and quartz phenocyrats that are less than $1=1$ in diaseter. Sall green chips of aphanitic volcanic rock are comon. On1t 1ncludes purple quartzose sandstone and conglomerate. Locally as much as 400 m thick 
and leaser plagloclase and biotite. Ranges from 0 to over 200 ath1ck

TV VOLCANIC ROCKS, UNDIVIDED (MIOCENE NND/OR OLIGOCENE)-Bydrotheraally eltered rocks of uncertain stratigraph1c 1dentity along the Bible Spring fault zone

carbonate rocks. In many outcropa the brecc1s has been wholly allicified to fora jasperoid that has experienced a second ep1sode of brecciation. The voids between clasts are partly filled with quartz crystals. The first brecclation was 1ikely associated with imbricate thrusting before deposition of Sawtooth Peak Poraation (Tsp), possibly during the sase ep1sode of attenuation faulting documented in areas to the north (Hintze, 1978; Best and Hintze, 1980) that foras both ledgy and rubble-covered slopes. Thickness uncerta1n but probably about 150 .

DNTE CRISTO LInesToNR (MISSISSIPPIAN)-Gray, thin-bedded 11mestone and dolomite containing thin beds of black chert, and fossils of brachlopods, rugose corals, crinold ossicles, and bryozoan fragsents. This unit has been described in an area $70 \mathrm{ka}$ to the east of map area near Milford by Welsh (1973). A thickness of only 60 is exposed in map area

andstone, doloaite, and alnor 11meatone. The sandatone is tan and forns ledgy slopes, 1s thin bedded, fine to medium grained, and composed wostly of subrounded quartz grains. Dolowite is dark gray to black, thin to thick bedded, fine to coarse grained, locally cherty, and contalns stromatoporold structures. The faulted section 1 s at least $200=$ thick

CRYSTAL PASS DOLOMITE MERBER OP SULTAN LIMESTONE (UPPER DEVONIAN)pine-grained, 11ght-gray to tan dolomite. Incomplete section of uncertain total thickness

LKETOWN DOLOMTIE (SILURIAN)--Fine- to medium-gralned ledge- and cliff-foraing doloalte that is somentat brecelated and 11ght gray in lower half of unit and 11ght-gray with darker gray interbeds in upper half. Irregularly shaped ansses of chert are sparse. Un1t appears to be about $500 \equiv$ th1ck

ELY SPRINGS DOLOKITE (UPPER ORDOVICLNN)-Brecc1ated, medium-gra1ned brown-gray doloalte. More poorly exposed then the overlying Laketoin Dolonite. Upper part 1s somevhat fossillferous and cherty. Un1t 18 about $150 \mathrm{~m}$ thick

EURERA QUARTZITE (MTDDLE ORDOVICINN)-Th1ck beds of tan to 11ghtgray, medium to fine-grained orthoquartzite that veathers orange brown to white. Coemonly pock-anked by weathering and stained by lianite. Section 18 folded and brecelated and $1 \mathrm{~s}$ estimated to be about 30 = thick 
ORDOVICINA ROCKS UNDIVIDED--Includes in descending order, Middle Ordoviclan Crystal Peak Dolowite, Mateon Ranch Quartzite, Lehanan Poraation, Kanosh Shale, Juab Limestone, and Lower Ordovic1an Wah Wah Limestone. These units are thick and vell def ined to the north (see Best and H1ntze, 1980), but are too thin in auch of the aap area to be subdivided. Total th1ckness fust southeast of Arrowhead Pass is $320 \mathrm{~m}$

ruNoSH SHALE (MIDDLE ORDOVICTAN)-Th1n-bedded, fossiliferous shaly

11meatone interbedded with fissile, phyllitic, dark-browa to

ollve shale. Typically is a slope-foraing unit, and tends to

be poorly exposed. Reglonal thickness 1s about $150 \mathrm{~m}$

FILLYORE FORMATION (LOHER ORDOVICINN)--Interbedded thin-bedded,

ledgy gray limestone and poorly exposed slope-foralng yellow

gray shale. The 11mestone 1s comanonly an intraforaational

conglomerate of flat pebbles of sandy limestone in a finer

matrix. Only faulted sections 300 a thick are exposed

BOUSE LIRESTONE (LCHER ORDOVICLAN)--Gray, medium- to thick-bedded,

fine-grained 11mestone that has sparse chert and bloclastic

beds. 100 a thick

$06 \mathrm{n}$

MOTCR PEAR FORYATION (LOTER ORDOVICIAN? AND UPPER CAKBRIAN)--OnIY a partial section of 11ght- to mediur-gray dolomite exposed

Possibly of Devonian or Mississippian age
MOTABLE STRDCTURAL, FEATURES

The rocks in the Steamboat Mouritaln and Bible Spring quadrangles reflect three ep 1sodes of deforantion: (1) thruating and attenuation of Paleozolc units presuably during the Late Cretaceous as docusented in areas to the north (H1ntze, 1978; Best and H1nze, 1980); (2) caldera subsidence accompanying extrusion of the Wah Wah Springs Tuff Meaber of the Needles Range Poration during 011gocene time about $30 \mathrm{~m} . \mathrm{y}$. ago, followed by resurgent doming apparently with1n 2 willion years; (3) Miocene block faulting and t1ling. The nature of the 011gocene events are obscured by Miocene volcanisa and tectonisa. The mostly undeformed 12-a.y.-old rhyolite flows of Steanboat Mountain rest unconforaably on t11ted and eroded older units.

\section{Indian Peak Calder}

The Indian Peak caldera 1s a a jor collapse structure that formed during eruption of the Wah Wah Springs Tuff Meaber 30 m.y. ago. It 1s clearly exposed in the Miners Cabin Wash, Buckhorn Spring, and P1nto Spring quadrangles to the north (Best and others, 1979; Grant and Best, 1979), but 1s mostly concealed beneath younger Miocene volcanic rocks and Quaternary alluvium in the Steamboat Mountain and Bible Spring quadrangles. Dnequivocal caldera fill units belong1ng to the Wah Wah Springs Member (Tnw1 and Tab) are exposed in the northvest part of the aap area. Exposures of the Wah wah Springs Meaber around Bible Spring are of the 11thic unit (Tnv1), aainly in fault slices, and no breccia (Tab) 1s exposed. The Wah Wah Springs here appears to be only a hundred meters or so thick coapared to a more noranl th1ckness within the caldera of a kilometer or more. Concelvably, th1s abooranlly thin wah Wah Springs 11thic tuff could have accunulated outside the caldes where there were no topographic restra1nts to cause puddling.

Alternitively, these exposures my be only the top of a very thick section of 
the unit and the opatially assocluted etposures of Eacalante Desert Poration (To) could represent landslide ansses within the Vah Wah Springs unit, such as occur north of Indian Peak in the Miners Cabin Wash quadrangle (Best and others, 1979). To the east in the eastern part of the adjacent Mountain Spring Peak quadrangle, exposed Wah Wah Spring Meaber rocks belong ent1rely to the nonlith1c outflow unit, but the position of the structural rim of the caldera has not been located closely and could 11 e either east or west of the exposures at Bible Spring. The best indirect evidence of the position of the caldera anrgin cones froe opposing dips in the coapaction follaton foraing an antiform in the Lund Tuff Meaber ( $\mathrm{Tn} 1)$ 1n secs. 9 and 16 one alle east of B1ble Spring. These dips ma reflect compaction over a buried topographic proulnence, possibly the topographic vall of the caldera, or of intrusion to shallow levels of Miocene sillcic magma, along the structural margin.

Although caldera fill coaposed of the Wah Wah Springs Member (Tawl and Tab) 1s structurally and topographically high froe the Steamboat Mounta1n quadrangie northuard for 16 alles to Indian Peak, the exact t1me of th1s uplift 1s uncertalr. In the model of Salth and Balley (1968), resurgent uplift of the caldera floor occurs soon after subsidence. In the central part of the Steamboat Mountain quadrangle, the mafic member of the foration of Blavn kash (Tba) was deposited directly on the 11th1c intracaldera unit of the Wah Wah Springs Tuff Meaber that is perhaps an order of angnitude thinner than to the north 1n the P1nto Spring quadrangle (Grant and Best, 1979); this suggests considerable erosion before the mafic member vas deposited. Locally In the central part of the Steasboat Mountain quadrangle there are thin deposits of the tuff of Ryan Spring (Tr) on caldera fill that are capped by the Lund Member ( $\mathrm{Ta} 1$ ), or else the Lund 11es directly on f111; these relations suggest, but do not prove, uplift of the caldera fill had occurred prior to deposition of the Lund Tuff Meaber that has an age of $28 \mathrm{~m}$.y. The tuff of Ryan Spring ( $T r$ ) 1s thicker to the southeast and espec1ally to the northeast wh1ch would be expected 15 the core of the resurgent uplift lay to the north and weat of the Steamboat Mountain quadrangle.

In the southeastern part of the Steamboat Mowstain quadrangle and the southern B1ble Spring quadrangle there 1s a reanarkably thick sect1on, over $4 \mathrm{~km}$, of post-caldera-fill rocks below the mafic flow member (Tbm) that is essentially absent in the central and northwestern parts of the Steanboat Mountain quadranole (see cross-section $\mathrm{BB}^{\prime}$ ). This thick section plus the rhyolit1c tuffs ( $T t$ ) and the maf1c flow meaber ( $T b a$ ) have been t1lted to the southeast along a postulated concealed M1ocene fault (see below). The postcaldera-f111 units th1cken abruptly southeast of a northeast-atrik1ng fault zone along which the last movement dropped the northuest side down. However, prior to deposition of the abnormally thick section, there wust have been considerable displacement in the opposite sense along a precursor fault zone in about the sase place. It 18 uncerta1n whether this 011gocene faulting was associated in sose vay with resurgence of the Indian Peak caldera or vith caldera subsidence accompanying extrusion of the voluminous Lund Tuff Member. Possible Source Caldera for che Isoe Poration

Rocks assigned to the Isom Porantion compose a section at lesst 800 a thick fust north of Negro L1za Wash in the southwest corner of the quadrangle and then thin abruptly to as little as 80 a farther north. A variety of extrusive rocks with aparse phenocrysts of plagioclase and pyroxene anke up th1. sect1on, but only the upper part has ash-flow tuff typical of the Isom seen 2n surrounding areas. Bedded volcanic sandstones within the thick section occur along the boundary of secs. 12 and 13, T. 32 S., R. 18 w. The thickened pile of Isos-1ike rocks suggests accumulation in a subsiding caldera 
accoapanying their extrusion. However, there are no interningled brecelan that could anifest crumbling of the topographle wall of auch a caldera. Younger Miocene rocks and Quaternary alluviua conceal this possible caldera to the south and west and make interpretation difficult. Miocene fauliting

The northest-trending Bible Spring fault zone in the southeastern part of the ap area localized major displecement and assoclated hydrotheras alteration that 1nvolved most of the volcanic rock units. Movement along the zone formed a network of horsts and grabens, and locally produced sufficlent topographic offset to result in local debris slides, now seen as landslide and fluvial deposits (T1f). The faults dip ateeply and appear to have had predominant d1p-slip offset; the latest movement, hovever, was largely strikeslip as shown by any exposures of fault surfaces with subhorizontal slickensides. Nothing in the pattern of aap units, hovever, indicates that the principal displacesent in the zone is atrike slip.

$A$ north-trendiag vertical fault with apparent left-lateral strike-slip d1splacement 11 es fust vest of Bull Valley.

$A$ anjor fault, offset down to the northwest, appears to exist beneath the rhyolitic rocks in the south-central part of the map area. Conceivably, it runs from the vicinity of Pace and Hustang Springs along the south edge of the aap area northeastward so that 1t passes near Typho1d Spring. Th1s postulated fault would account for the repetition of the post-Tr units between w11son Canyon and the Bible Spring fault zone as vell as the1r southeast dip.

\section{REFERENCES}

Abbott, J. T., Beat, M. G., and Morr18, B. T., 1981, Preliminary geologic map and cross sections of the P1ne Grove-Blavn Mountain area, Beaver County, Utah: U.s. Geological Survey Open-pile Report 81-525.

Best, M. G., Grant. S. R., and Holaes, R. D., 1979, Geologic aap of the M1ners Cabin Wash and Buckhorn Spring quadrangles, Beaver County, Utah: v.s. Geological Survey Open-File Report 79-1612.

Best, M. G., and Ke1th, J. D., 1979, Map showing volcanic geology of the Observation Knoll and the Tetons quadrangles, Beaver and Iron Counties, Utah: U.S. Geological Survey Open-F1le Report 79-1611.

Best, M. G., and Hintze, L. F., 1980, Geologic map of the Sawtooth Peak quadrangle, Beaver County, Utah: U.S. Geological Survey Miscellaneous Field Studies Map MF-1152, scale 1:24,000.

Fleck, R. J., Anderson, J. J., and Rowley, P. D., 1975, Chronology of midTertiary volcanism in B1gh Plateaus region of Utah: Geological Society of Amer1ca Spec1al Paper 160, p. 53-61.

Grant, S. K., and Best, M. G., 1979, Geolog1c map of the P1nto Spring and part of the Atch1son Creek quadrangles, Beaver and Iron Count1es, Utah: v.S. Geological Survey Open-P11e Report 79-1656.

H1ntze, L. P., 1978, Sevier orogenic attenuation faulting in the F1sh Springs and House Ranges, western Utah: Brighan Young Dnivera1ty Geology Studies, v. 25, pt. 1, p. 11-24.

Satth, R. L., and Bally, R. A., 1968, Resurgent cauldrons, 保 R. R. Coats, R. L. Hay, and C. A. Anderson, editors, Studies in volcanology: Geological Society of America Memolr 116, p. 613-662. 
Welsh, J. B., 1973, Paleozolc and Mesozolc stat1graphy of the Kilford area, Beaver County, Utah: Salt Lake C1ty, Utah Geological Association Publication 3, Utah Geological and Mineralogical Survey, p. 9-12. 


\section{DEPARTMENT OF THE INTERIOR}

UNITED STATES GEOLOGICAL SURVEY

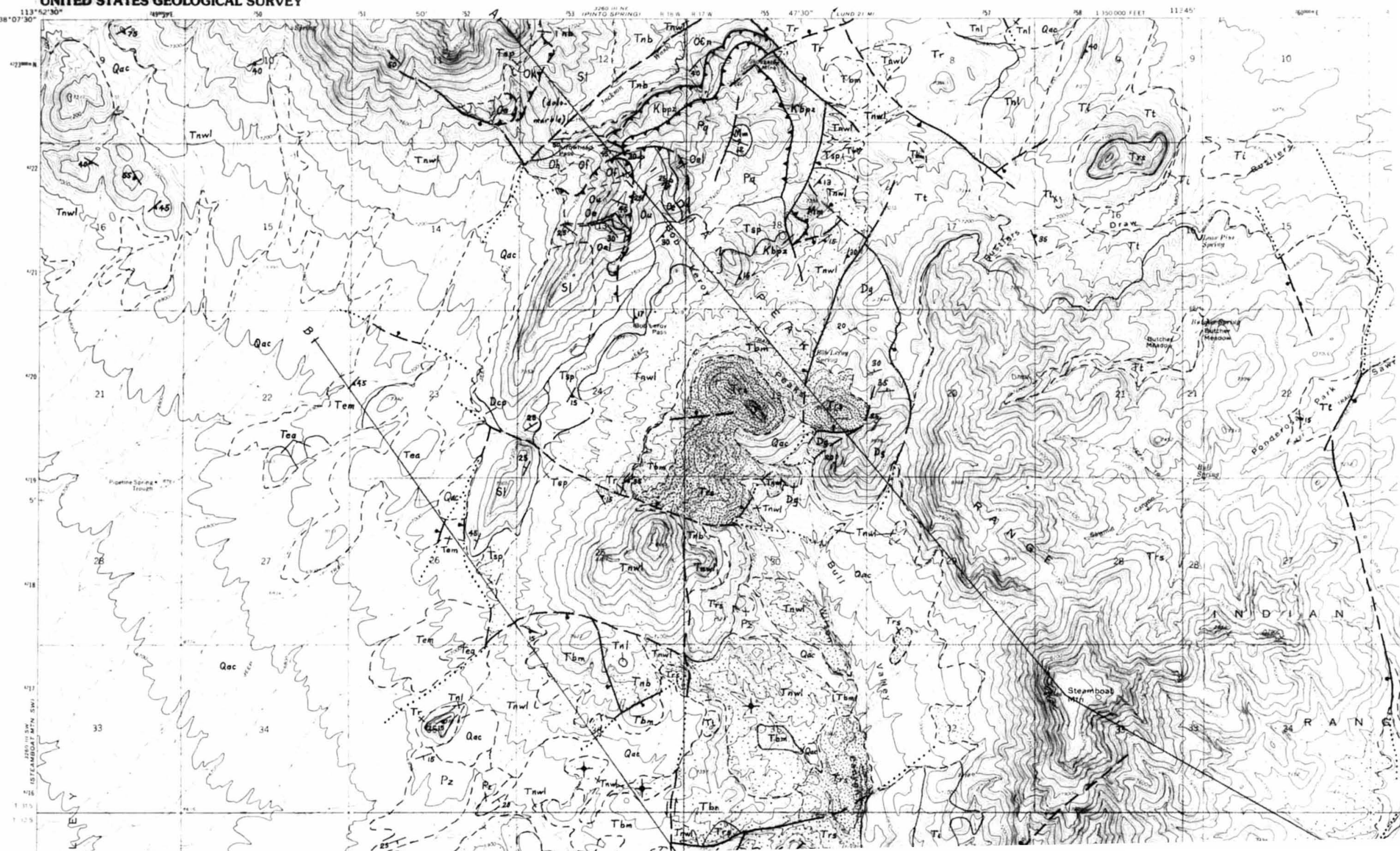




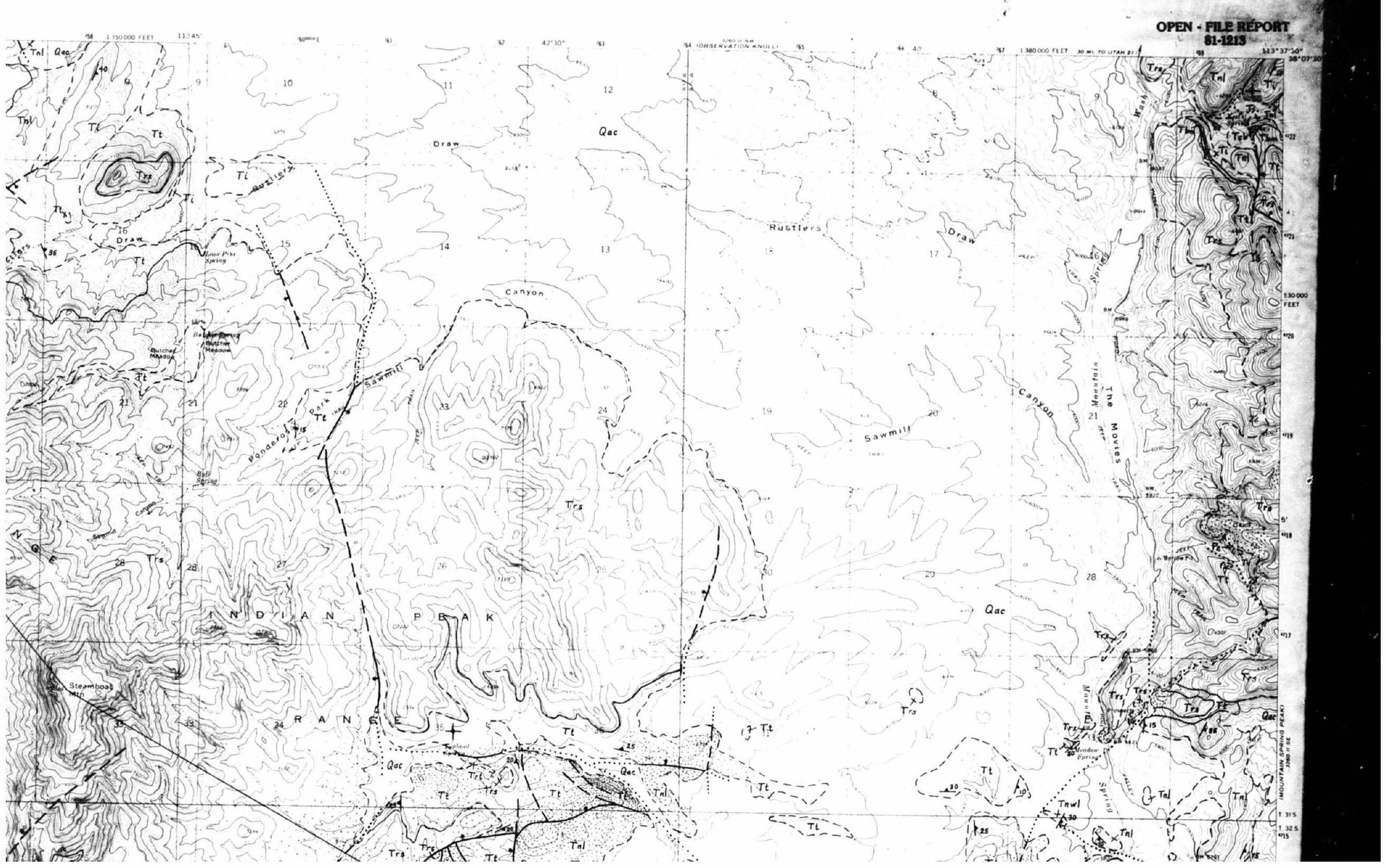




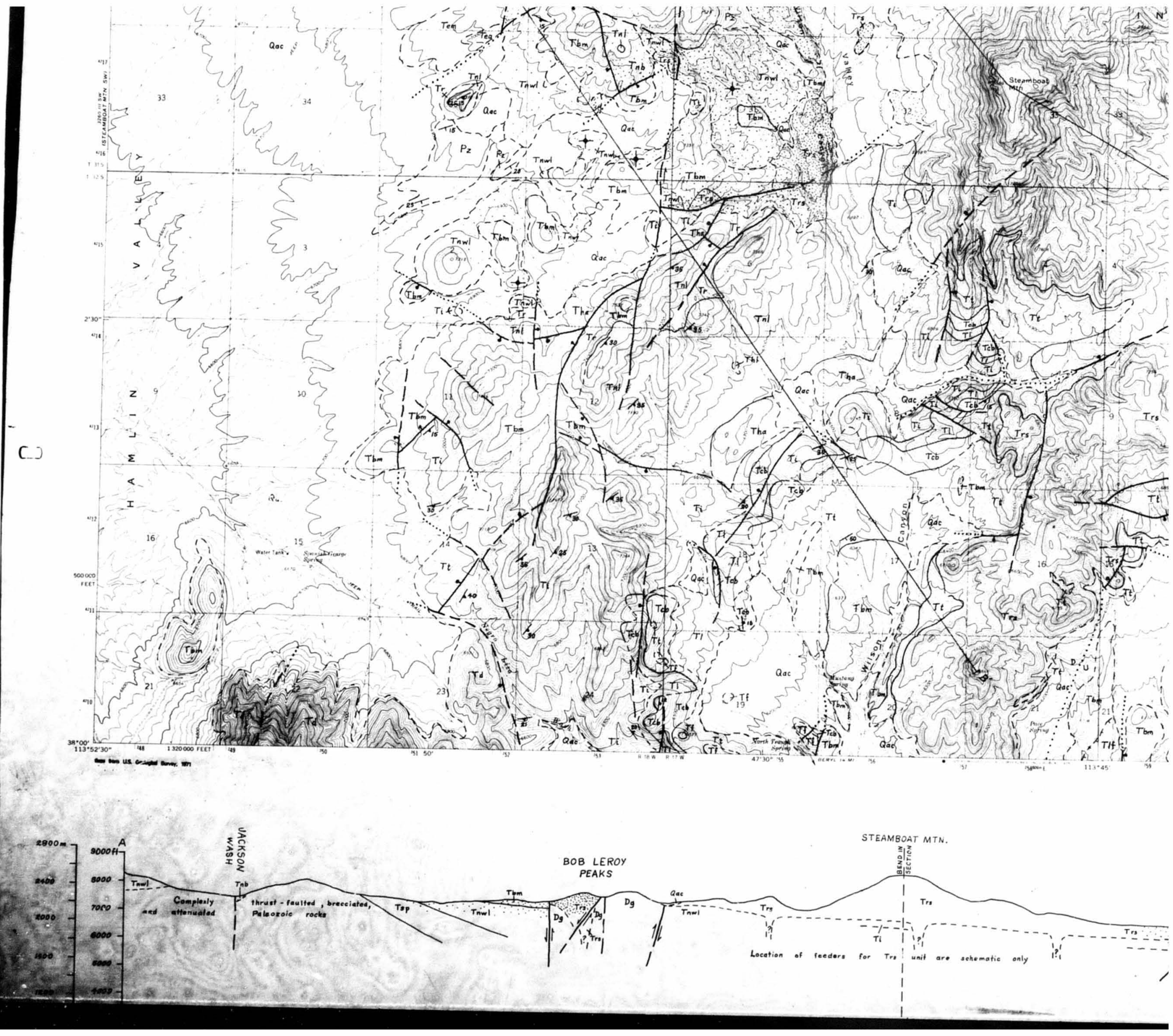




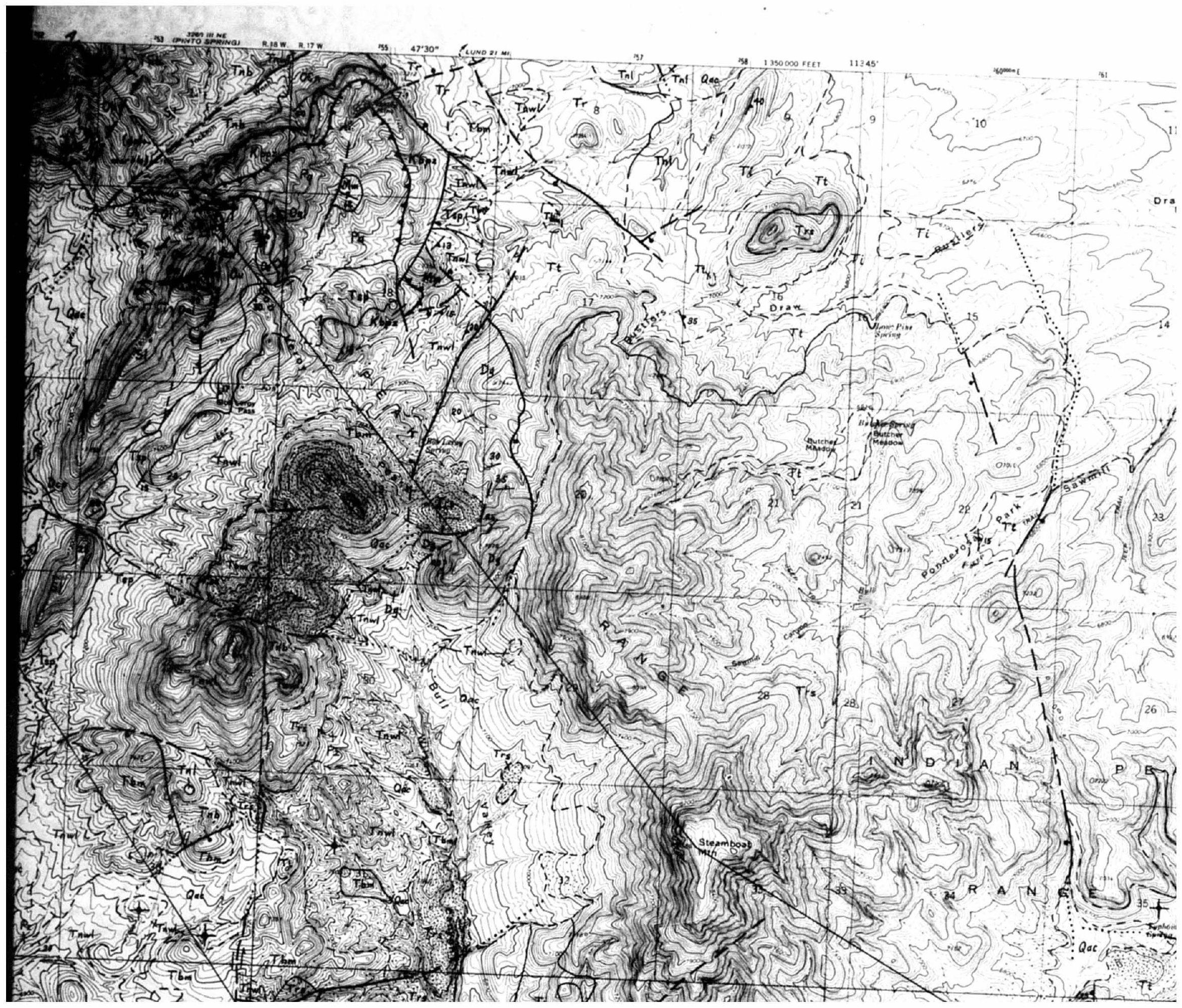




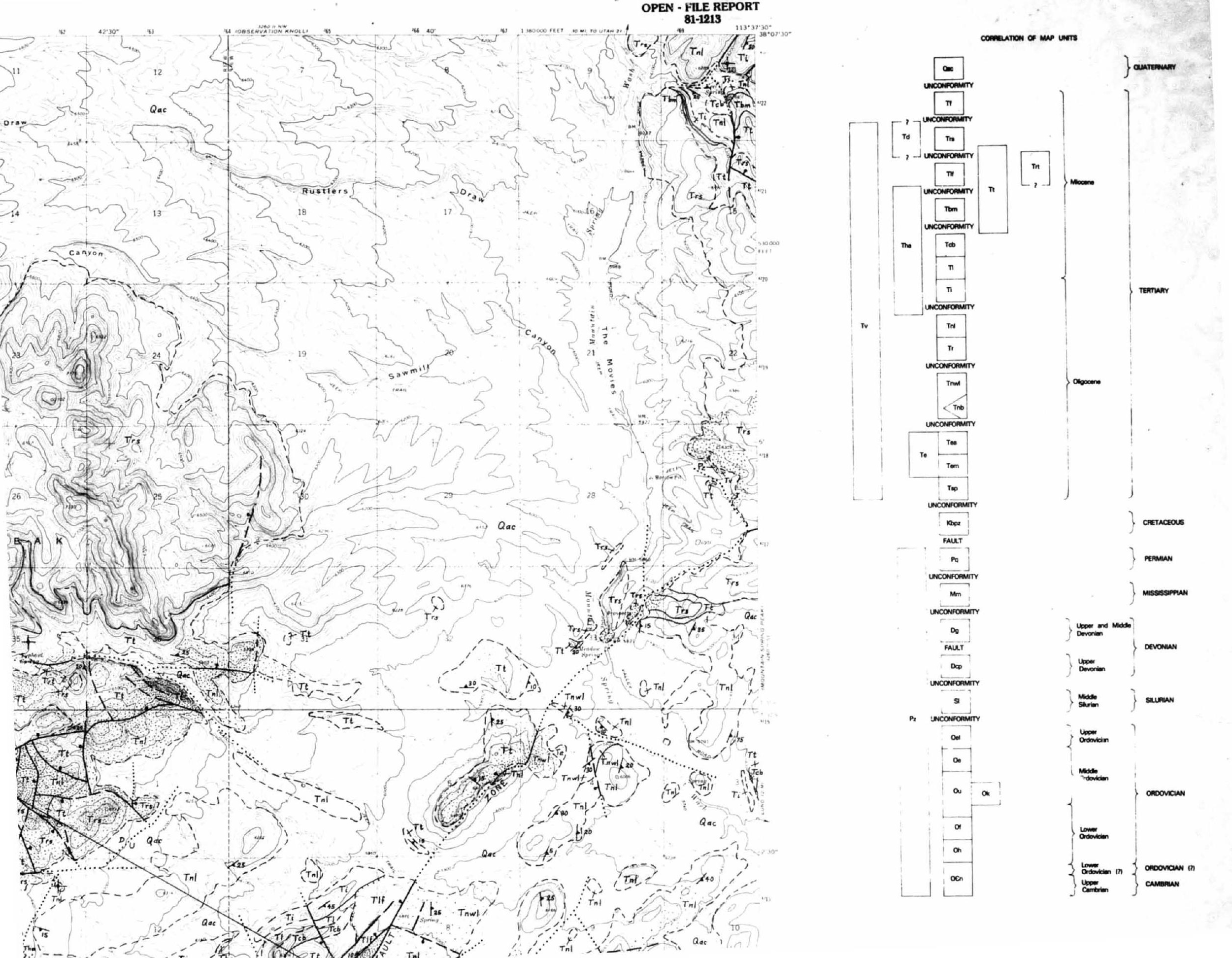




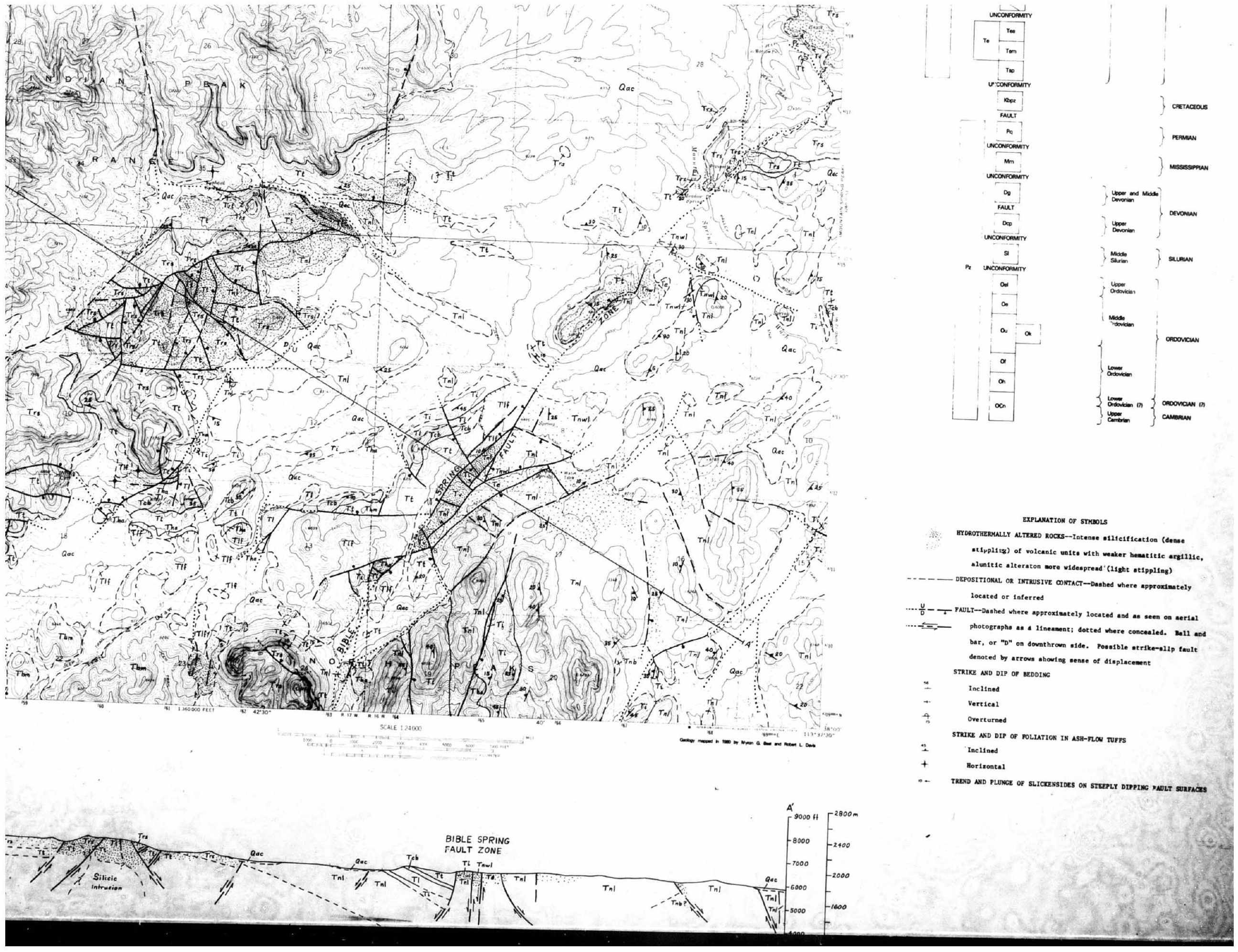




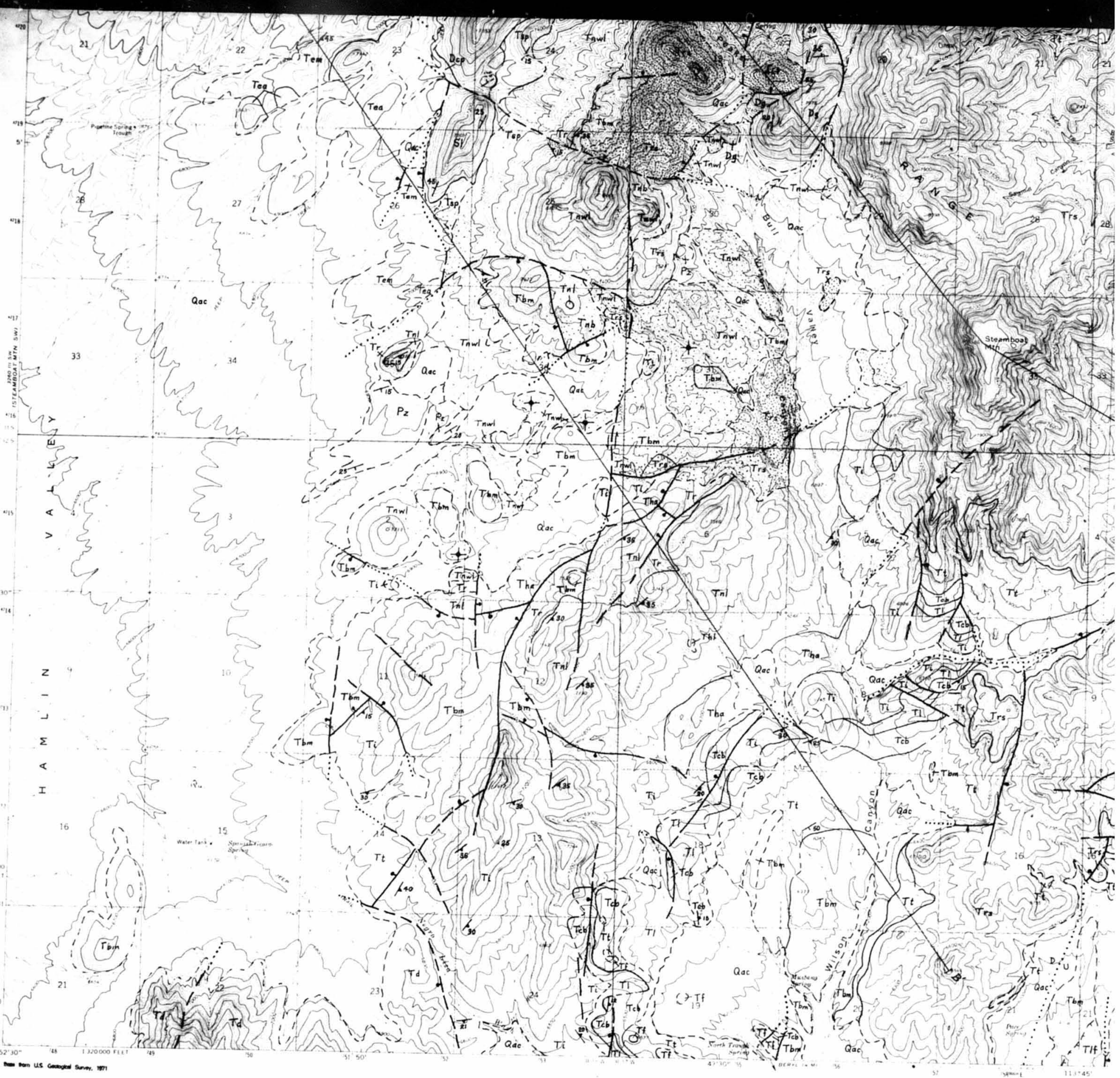




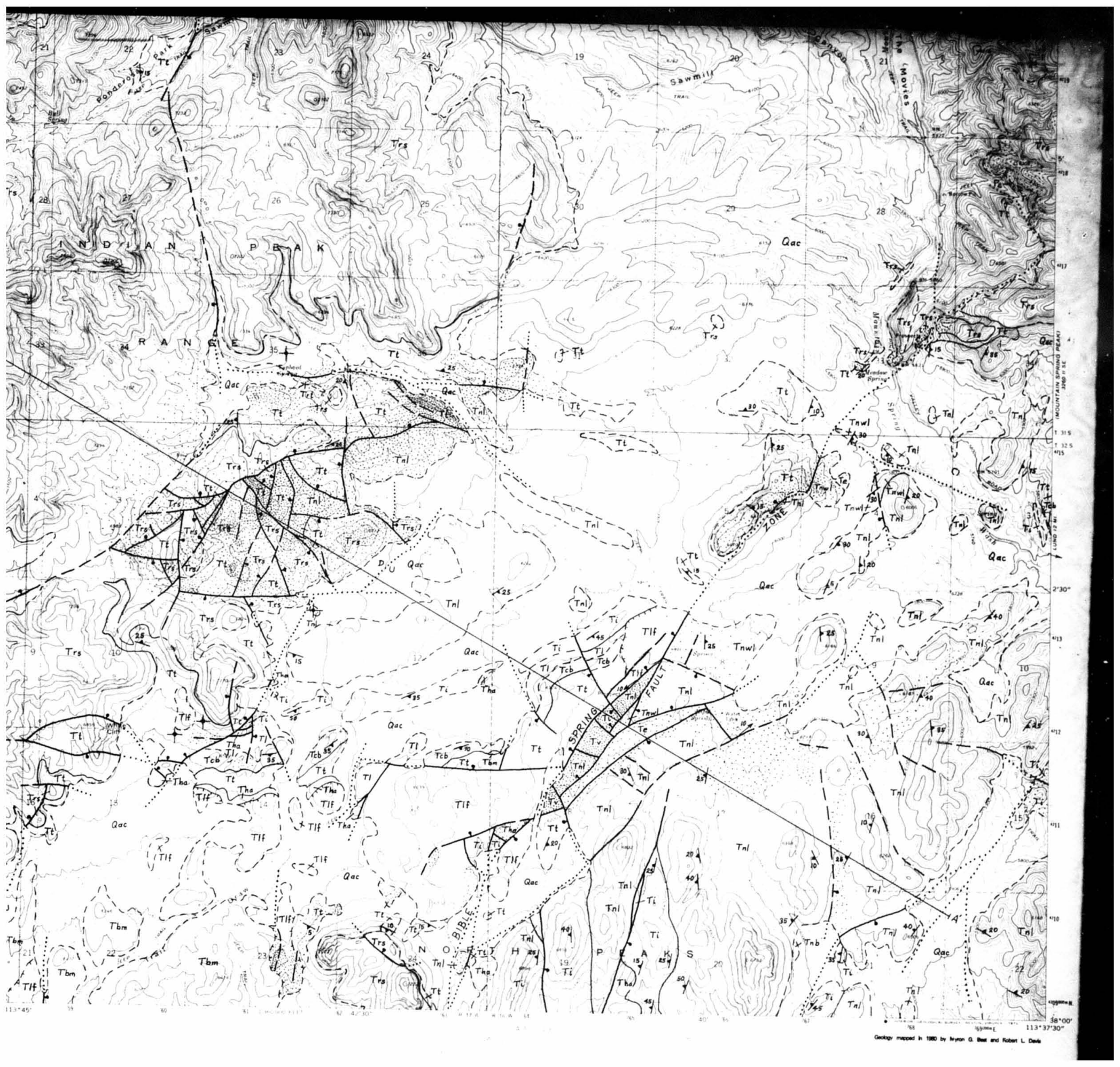



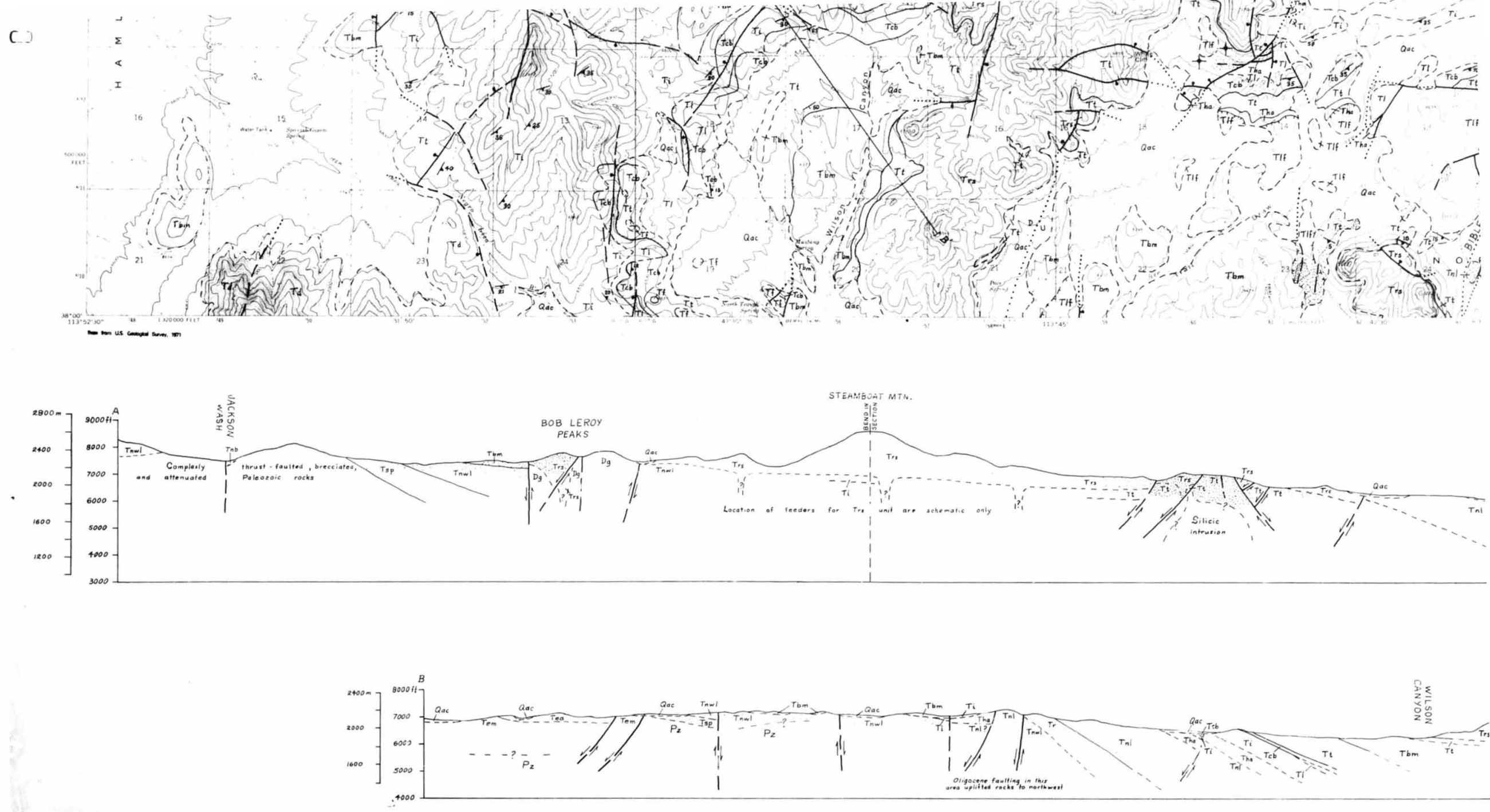

GEOLOGIC MAP OF THE STEAMBOAT MOUNTAIN AND BIBLE SPRING QUADRANGLES, WESTERN IRON O Myron G. Best and Robert L. Davis 


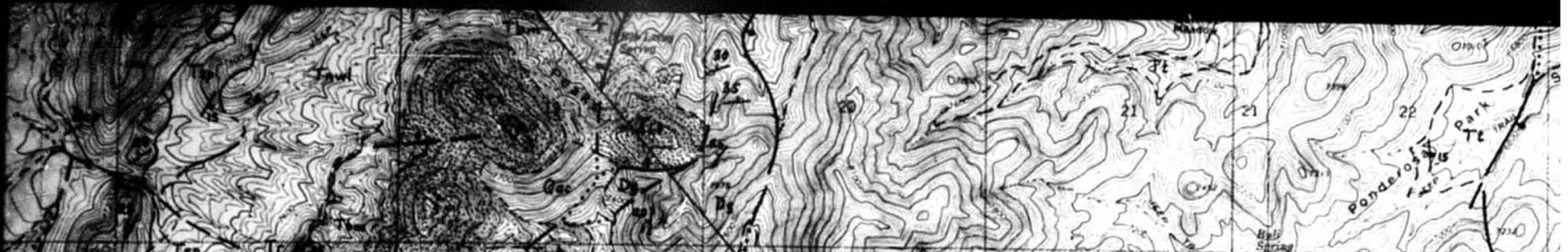

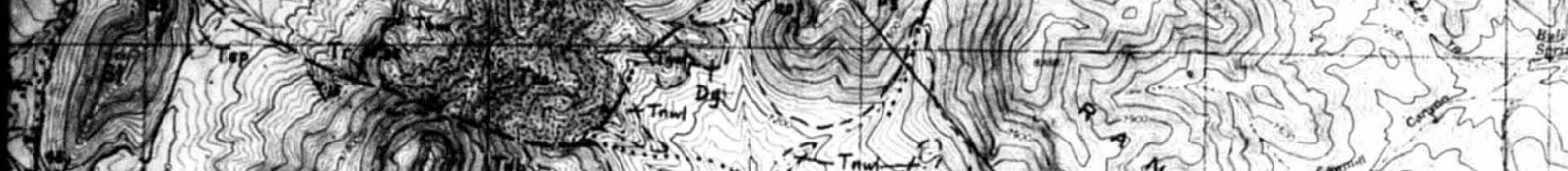

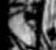

ate

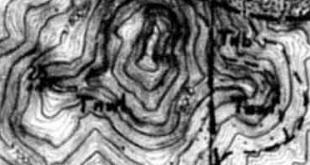

(i)

bat

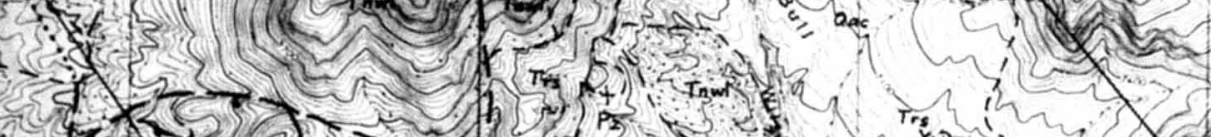

21

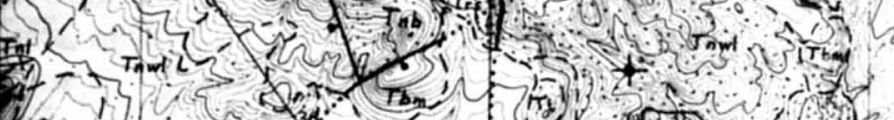

are

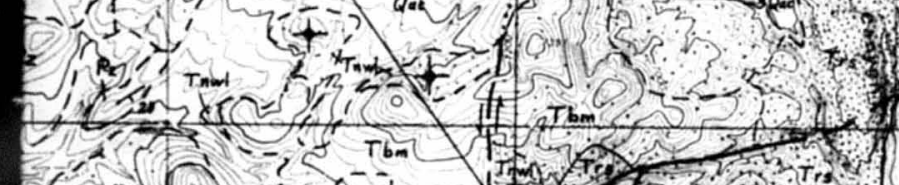

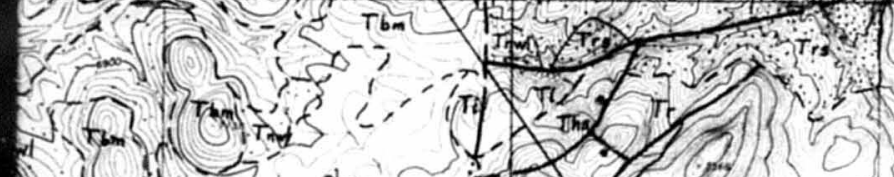

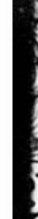
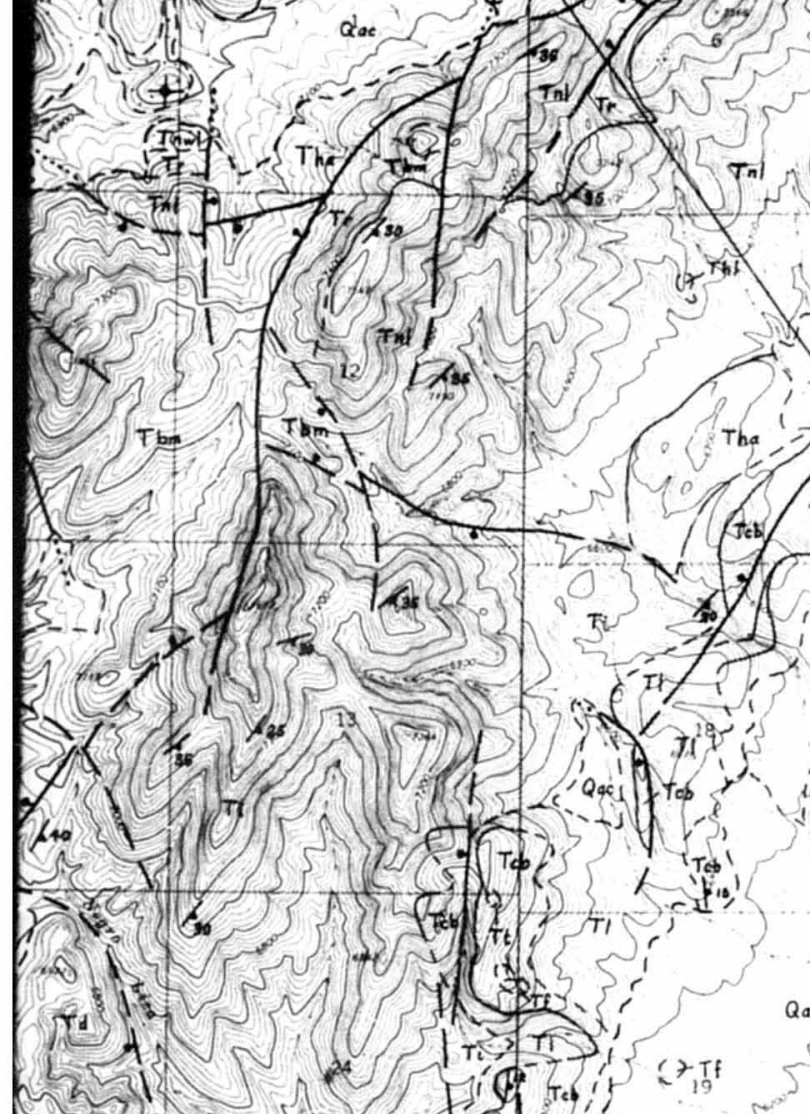
R. $\left.{ }^{3}\right]^{4}$ 2. 


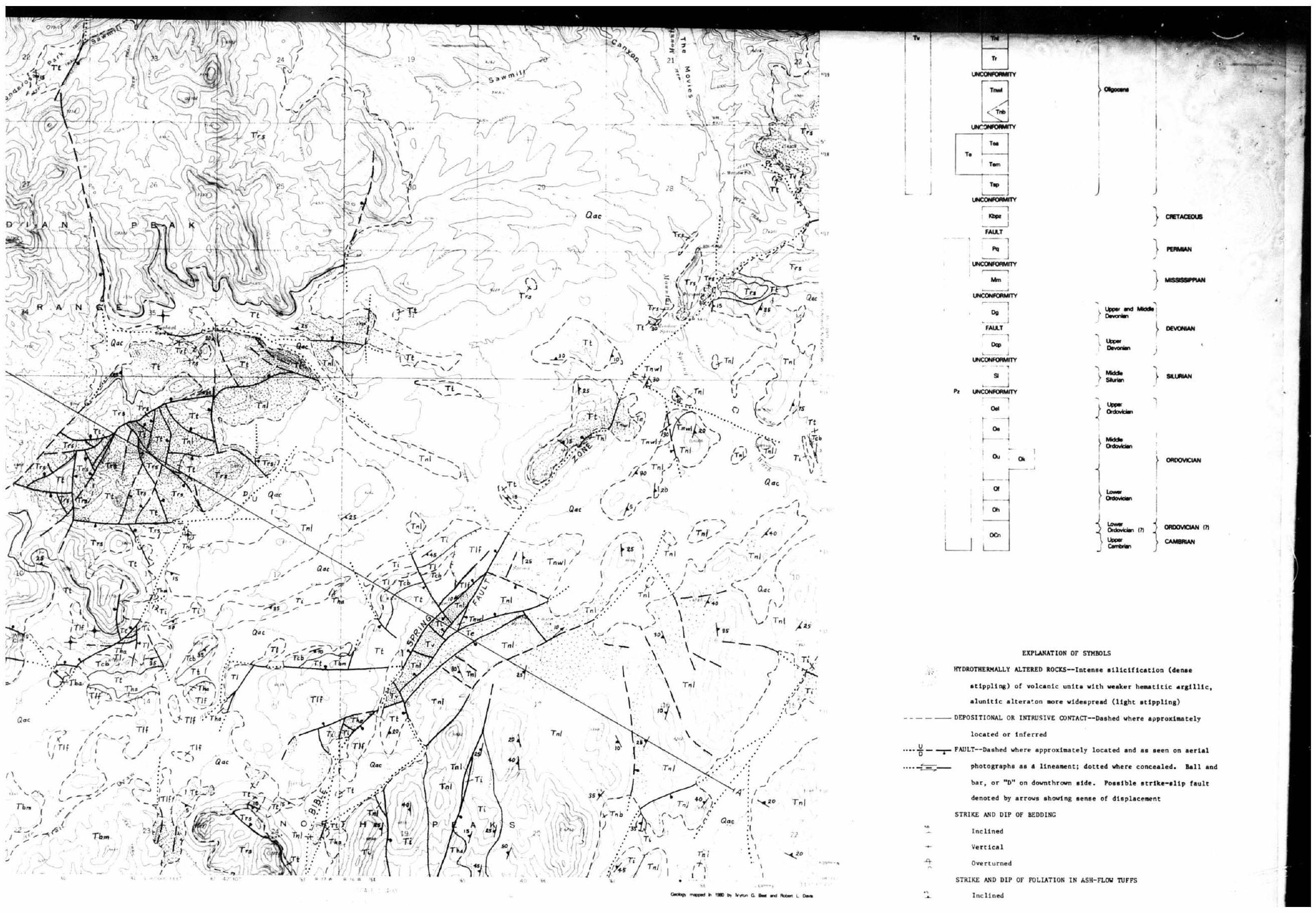


